\title{
Distribution, natural history and conservation status of two endemics of the Bolivian Yungas, Bolivian Recurvebill Simoxenops striatus and Yungas Antwren Myrmotherula grisea
}

\author{
SEBASTIAN K. HERZOG, A. BENNETT HENNESSEY, MICHAEL KESSLER \\ and VÍCTOR H. GARCÍA-SOLÍZ
}

\begin{abstract}
Summary
Since their description in the first half of the $20^{\text {th }}$ century by M. A. Carriker, Bolivian Recurvebill Simoxenops striatus and Yungas Antwren Myrmotherula grisea have been regarded as extremely poorly known endemics of the Bolivian Yungas and adjacent humid foothill forests. They are considered 'Vulnerable' under the IUCN criteria of small population, predicted population decline (criterion C2a) and, in the case of Bolivian Recurvebill, small extent of occurrence (criteria $\mathrm{B}_{1} \mathrm{a}+\mathrm{b}$ ). Here we summarise the information published to date and present extensive new data on the distribution (including the first records for extreme southeast Peru), natural history, population size and conservation status of both species based on field work in the Bolivian Andes over the past 12 years. Both species primarily inhabit the understorey of primary and mid-aged to older regenerating forest and regularly join mixed-species foraging flocks of insectivorous birds. Bolivian Recurvebill has a strong preference for Guadua bamboo, but it is not an obligate bamboo specialist and persists at often much lower densities in forests without Guadua. Yungas Antwren seems to have a preference for dense, structurally complex understorey, often with Chusquea bamboo. Both species are distributed much more continuously at altitudes of mostly 60o-1,500 m, occupy a greater variety of forest types (wet, humid, semideciduous forest) and have a much greater population size than previously thought. Consequently, none of the IUCN criteria currently used to assign 'Vulnerable' status to both species actually apply, and we recommend them to be downlisted to 'Near Threatened'.
\end{abstract}

\section{Resumen}

Desde su descripción en la primera mitad del siglo 20 por M. A. Carriker, el Ticotico Boliviano Simoxenops striatus y el Hormiguerito Boliviano Myrmotherula grisea han sido considerados como especies muy pobremente conocidas y endémicas de los Yungas de Bolivia y bosques húmedos del pie de monte colindante. Son considerados como Vulnerable a la extinción bajo los criterios de la UICN de una población pequeña, un declive poblacional predicho (criterio C2a) y, en el caso del Ticotico Boliviano, una extensión de presencia (área de distribución) pequeña (criterios $\mathrm{B}_{1} \mathrm{a}+\mathrm{b}$ ). En el presente trabajo resumimos la información publicada hasta la fecha, y presentamos datos nuevos amplios sobre la distribución (incluyendo los primeros registros para el extremo sudeste del Perú), historia natural, el tamaño poblacional y estado de conservación de ambas especies, basándonos en nuestro trabajo de campo en los Andes de Bolivia durante los últimos 12 años. Ambas especies principalmente habitan el sotobosque de bosque primario y de bosque en regeneración de edad media y maduro, y a menudo se unen a bandadas mixtas de 
forrajeo de aves insectívoras. El Ticotico Boliviano tiene una preferencia marcada para bambú del género Guadua (tacuara), pero no es un especialista obligado de bambú y persiste en bosques sin tacuara, aunque a menudo a densidades mucho mas bajas. El Hormiguerito Boliviano parece tener una preferencia para un sotobosque denso, con una estructura de la vegetación compleja y a menudo con bambú del género Chusquea. A diferencia del estado del conocimiento anterior, ambas especies tienen una distribución mucho más continua, en su mayor parte a altitudes de 600-1500 m, habitan una mayor variedad de tipos de bosque (muy húmedo, húmedo, semi deciduo) y tienen un tamaño poblacional mucho más grande. Como consecuencia, ninguno de los criterios de la UICN actualmente usados para asignar la categoría Vulnerable a ambas especies aplican, y recomendamos que sean cambiadas de categoría a Casi amenazado.

\section{Introduction}

The Bolivian Yungas are situated in Endemic Bird Areas 054 and 055 (Bolivian and Peruvian lower and upper Yungas, respectively; Stattersfield et al. 1998, www.birdlife.org/action/science/ endemic_bird_areas/index.html), both of which are considered of urgent conservation priority, and in the southern part of the Tropical Andes biodiversity and conservation hotspot of Myers et al. (2000). They extend from about $13^{\circ} 30^{\prime} \mathrm{S}$ in depto. La Paz to $18^{\circ} 00^{\prime} \mathrm{S}$ in depto. Santa Cruz and reach from Andean foothills (c. $500 \mathrm{~m}$ altitude) up to isolated Polylepis forest patches (to $c$. 4,200 m) above the closed timberline. The Yungas ecoregion is Bolivia's top priority for bird conservation (Herzog et al. 2005b) and contains about 600 (43\%) of Bolivia's c. 1,420 bird species (Hennessey et al. 2003b, authors' unpubl. data), including 14 Bolivian endemics and nearendemics, 43 restricted-range species (see Stattersfield et al. 1998) and 12 threatened species (see Hennessey et al. 2003b).

Up to the early 1990s the majority of ornithological field work in the Yungas and other regions in Bolivia was carried out by collecting expeditions primarily from North American museums, and specimen localities were far and few between. Not surprisingly, many bird species were considered poorly known (e.g., Remsen et al. 1982, 1987, 1988; Remsen and Traylor 1983; Remsen 1984; Parker et al. 1992). Over the past 1o to 15 years, however, our knowledge of bird distributions in the Bolivian Yungas has improved considerably (see, e.g., Perry et al. 1997, Herzog et al. 1999, Hennessey 2003a,b, Hennessey et al. 2003a, Hennessey and Gomez 2003, Herzog et al. 2005a, MacLeod et al. 2005), allowing for a reassessment of the natural history and conservation status of numerous species once considered poorly known (e.g., Bryce et al. 2005), including the threatened (BirdLife International 2000, 2004) Yungas endemics Bolivian Recurvebill Simoxenops striatus (Furnariidae) and Yungas Antwren Myrmotherula grisea (Thamnophilidae). Both are currently considered 'Vulnerable' under IUCN criteria of small population, predicted population decline and, in the case of Bolivian Recurvebill small extent of occurrence and area of occupancy (BirdLife International 2007a,b).

Bolivian Recurvebill is among the country's most poorly understood bird species. For over 50 years, this species was known from only five specimens, four of which were collected in the $1930 \mathrm{~s}$ by M. A. Carriker in humid Andean foothill forest (Vaurie 1980) at Santa Ana on the Río Coroico (670 m), depto. La Paz (Carriker 1935), and at El Palmar (80o m), depto. Cochabamba (Bond and Meyer de Schauensee 1941). The fifth specimen (housed at the Louisiana State University Museum of Natural Science) was collected in 1954 by F. Steinbach at Alto Palmar (1,100 m) in lower Yungas forest above El Palmar. In 1989, Parker et al. (1992) rediscovered the Bolivian Recurvebill at a new locality in the upper Río Saguayo valley (700-80o m) of Amboró National Park, depto. Santa Cruz, providing the first data on the species' natural history, and in 1992 Whitney et al. (1994) observed two birds $48 \mathrm{~km}$ by road southwest of Villa Tunari (1,080-1,090 m), depto. Cochabamba. Until recently, those were the only known localities for the Bolivian Recurvebill.

Yungas Antwren also was described by Carriker (1935) based on six specimens from Santa Ana (670 m), depto. La Paz. Two specimens at the Carnegie Museum, collected as early as 1917 at 
Cerro Hosane, Río Blanco (1,200 m), depto. Santa Cruz, had apparently been overlooked by Carriker (Remsen et al. 1982). A further specimen was collected in 1937 at El Palmar (800 m), depto. Cochabamba (Collar et al. 1992). From 1960 to 1981 an additional six specimens were collected (housed at the Louisiana State University Museum of Natural Science) at four localities in the departments of Santa Cruz (Santa Rita, 500 m), Cochabamba (Alto Palmar, 1,100 m) and La Paz (Serranía Bellavista, 1,550 m; Río Beni 20 km N Puerto Linares, $600 \mathrm{~m}$ ) (Remsen et al. 1982), and the species was observed by R. S. Ridgely (Remsen et al. 1982) north of Caranavi ( $1,400 \mathrm{~m})$, depto. La Paz, by Parker et al. (1992) in the upper Río Saguayo valley (650-1,000 m), depto. Santa Cruz, and by T. A. Parker (Collar et al. 1992) in the Serranía Raigones (800 m), depto. Santa Cruz. The only primary literature sources on the natural history of Yungas Antwren are Remsen et al. (1982), Parker et al. (1992) and Perry et al. (1997), who stressed the participation of the species in mixed-species foraging flocks from the understorey (Remsen $e$ al. 1982, Perry et al. 1997) to the lower canopy (Parker et al. 1992, Perry et al. 1997). Parker et al. (1992) stated that "this seemingly rare species is almost unknown in life." In fact, its loud song was unknown until 1996 when recorded for the first time by SKH (see Mayer 200o, Isler and Whitney 2002).

Over the past 12 years we obtained new data on the natural history of Bolivian Recurvebill and Yungas Antwren at a number of new localities in the Bolivian Yungas that notably increase their known distributional ranges. We also report on the first records of each species for extreme southeast Peru. Additionally, for the first time we present population density and size estimates for both species in the central portion of their range. In conjunction these data indicate that both species no longer merit threatened status, and that they should be downlisted to 'Near Threatened'. Our new locality data up to 1999 were included as personal communications in Threatened birds of the world (BirdLife International 2000, 2004), but they are presented formally and in detail herein. Data collected after 1999 are presented here for the first time. Because both species have very similar geographical distributions and often occur syntopically they are treated together rather than in separate publications.

\section{Study areas}

Most of the new distributional data presented here were obtained by the authors during rapid assessment surveys at a number of localities throughout the Bolivian Yungas. Coordinates, altitudes and brief notes on habitat for most localities are presented in Table $I$ and in the Supplementary materials. Two sites where we obtained important additional data are described in more detail here.

Cordillera Mosetenes, a remote mountain range located in the Andean foothill region of depto. Cochabamba, is separated from the main Andes by the Altamachi River. It is about $130 \mathrm{~km}$ long, $20-25 \mathrm{~km}$ wide (covering c. 3,000 $\mathrm{km}^{2}$ ), up to 2,050 $\mathrm{m}$ high and probably contains the largest completely uninhabited forest tract in Bolivia. It is one of the country's most humid regions and, due to its steep topography, is of extremely difficult access. Parts of the area are formally protected in Isiboro-Sécure Indigenous Territory and National Park. Bird surveys on Cordillera Mosetenes were conducted by SKH in a radius of $c .1 \mathrm{~km}$ around a small lagoon (Laguna Carachupa; Table I) from 28 August to 21 September 2003, with several trails reaching from stream valleys at about $1,200 \mathrm{~m}$ altitude to a mountain ridge at $1,600 \mathrm{~m}$. Rather than habitat characteristics, the sole criterion for choosing this site was the availability of an open area where a helicopter could land.

The vegetation at our study site on Cordillera Mosetenes (MK, unpubl. data) can be divided into five main categories. As determined from several over-flights by small airplane and helicopter by the authors, this habitat mosaic stretches across $80-90 \%$ of the area of Cordillera Mosetenes. (1) Mature forest was $20-25 \mathrm{~m}$ tall, had a rather open understorey and was restricted to scattered patches about $0.1-0.5$ ha in extent. Epiphytic plants were present in moderate density 
Table 1. Summary of Bolivian Recurvebill Simoxenops striatus (SIST) and Yungas Antwren Myrmotherula grisea (MYGR) locality data. See text and Supplementary materials for details on locality records. Coordinates and altitudes of literature and specimen localities were verified based on field knowledge of the authors, topographic maps and Google Earth.

\begin{tabular}{|c|c|c|c|c|c|}
\hline Locality & Coordinates & SIST & MYGR & $\begin{array}{l}\text { Protected } \\
\text { Area }\end{array}$ & Source \\
\hline $\begin{array}{l}\text { Curva } \\
\text { Alegre }\end{array}$ & $14^{\circ} \mathrm{O}^{\prime} \mathrm{S}, 68^{\circ} 58^{\prime} \mathrm{W}$ & $1,200 \mathrm{~m}$ & $1,200 \mathrm{~m}$ & - & $\begin{array}{l}\text { D.F. Lane and A. Cuervo, } \\
\text { pers. comm. }\end{array}$ \\
\hline $\begin{array}{l}\text { Palmerani- } \\
\text { Urubamba }\end{array}$ & $\begin{array}{l}14^{\circ} \mathrm{O}^{\prime} \mathrm{S}, 68^{\circ} 56^{\prime} \mathrm{W} \text { to } \\
14^{\circ}{ }^{\circ} 3^{\prime} \mathrm{S}, 68^{\circ} 54^{\prime} \mathrm{W}\end{array}$ & $1,100-1,200 \mathrm{~m}$ & $1,100 \mathrm{~m}$ & - & This study (SKH and VHG) \\
\hline Río Cocos & $14^{\circ} 4^{\prime} \mathrm{S}, 68^{\circ} 51^{\prime} \mathrm{W}$ & $900-1,100 \mathrm{~m}$ & $900-1,100 \mathrm{~m}$ & $\begin{array}{l}\text { Madidi } \\
\text { National Park }\end{array}$ & This study (SKH and VHG) \\
\hline Putina Puncu & $14^{\circ} \mathrm{O} 7^{\prime} \mathrm{S}, 69^{\circ} \mathrm{O} 1^{\prime} \mathrm{W}$ & - & $1,200 \mathrm{~m}$ & - & $\begin{array}{l}\text { D.F. Lane and A. Cuervo, } \\
\text { pers. comm. }\end{array}$ \\
\hline $\begin{array}{l}\text { Serranía } \\
\text { Eslabón }\end{array}$ & c. $14^{\circ} 17^{\prime} \mathrm{S}, 68^{\circ} 10^{\prime} \mathrm{W}(?)$ & $1,000 \mathrm{~m}$ & $?$ & $\begin{array}{l}\text { Madidi } \\
\text { National Park }\end{array}$ & $\begin{array}{l}\text { B.M. Whitney and } \\
\text { A. Perry, pers. comm. }\end{array}$ \\
\hline $\begin{array}{l}\text { Hacienda } \\
\text { Ubito }\end{array}$ & $14^{\circ} 22^{\prime} \mathrm{S}, 68^{\circ} 30^{\prime} \mathrm{W}$ & - & $850 \mathrm{~m}$ & $\begin{array}{l}\text { Madidi } \\
\text { National Park }\end{array}$ & Perry et al. 1997 \\
\hline Río Machariapo & $\begin{array}{l}14^{\circ} 24^{\prime} \mathrm{S}, 68^{\circ} 33^{\prime} \mathrm{W} \\
\text { to } 14^{\circ} 36^{\prime} \mathrm{S}, 68^{\circ} 28^{\prime} \mathrm{W}\end{array}$ & - & $95^{0-1,150 \mathrm{~m}}$ & $\begin{array}{l}\text { Madidi } \\
\text { National Park }\end{array}$ & $\begin{array}{l}\text { Perry et al. 1997, this } \\
\text { study }(\mathrm{ABH})\end{array}$ \\
\hline Yarimita & $14^{\circ} 33^{\prime} \mathrm{S}, 68^{\circ} 42^{\prime} \mathrm{W}$ & - & $900-1,000 \mathrm{~m}$ & $\begin{array}{l}\text { Madidi } \\
\text { National Park }\end{array}$ & This study $(\mathrm{ABH})$ \\
\hline $\begin{array}{l}\text { San Miguel } \\
\text { Chico }\end{array}$ & $14^{\circ} 39^{\prime} \mathrm{S}, 68^{\circ} 37^{\prime} \mathrm{W}$ & $1,650-1,700 \mathrm{~m}$ & - & $\begin{array}{l}\text { Madidi } \\
\text { National Park }\end{array}$ & Hennessey 2003a \\
\hline $\begin{array}{l}\text { Cerro } \\
\text { Asunta Pata }\end{array}$ & $15^{\circ} \mathrm{O}^{\prime} \mathrm{S}, 68^{\circ} 29^{\prime} \mathrm{W}$ & $1,200-1,300 \mathrm{~m}$ & $1,300 \mathrm{~m}$ & $\begin{array}{l}\text { Apolobamba } \\
\text { Integrated } \\
\text { Natural } \\
\text { Management } \\
\text { Area }\end{array}$ & $\begin{array}{l}\text { SIST: } \\
\text { This study (SKH and MK); } \\
\text { MYGR: S.W. Cardiff and } \\
\text { J.V. Remsen, pers. comm. }\end{array}$ \\
\hline Serranía Beu & $\begin{array}{l}15^{\circ} \mathrm{O}^{\prime} \mathrm{S}, 67^{\circ} 35^{\prime} \mathrm{W} \\
\text { to } 15^{\circ} \mathrm{O} 4^{\prime} \mathrm{S}, 67^{\circ} 36^{\prime} \mathrm{W}\end{array}$ & $800-1,250 \mathrm{~m}$ & - & $\begin{array}{l}\text { Pilón } \\
\text { Lajas Biosphere Reserve }\end{array}$ & Hennessey et al. 2003a (ABH) \\
\hline Serranía Pilón & $15^{\circ} 09^{\prime} \mathrm{S}, 67^{\circ} 06^{\prime} \mathrm{W}$ & - & $850 \mathrm{~m}$ (vagrant) & $\begin{array}{l}\text { Pilón } \\
\text { Lajas } \\
\text { Biosphere Reserve }\end{array}$ & Hennessey et al. 2003a (SKH) \\
\hline
\end{tabular}


Table 1. Continued.

\begin{tabular}{|c|c|c|c|c|c|}
\hline Locality & Coordinates & SIST & MYGR & $\begin{array}{l}\text { Protected } \\
\text { Area }\end{array}$ & Source \\
\hline Serranía Cuchilla & $15^{\circ} 15^{\prime} \mathrm{S}, 67^{\circ} 08^{\prime} \mathrm{W}$ & $800-850 \mathrm{~m}$ & - & $\begin{array}{l}\text { Pilón } \\
\text { Lajas Biosphere Reserve }\end{array}$ & Hennessey et al. 2003a (ABH) \\
\hline $\begin{array}{l}\text { Río Beni } \\
\text { N Puerto Linares }\end{array}$ & $15^{\circ} 25^{\prime} \mathrm{S}, 67^{\circ} 29^{\prime} \mathrm{W}$ & - & $600 \mathrm{~m}$ & - & Remsen et al. 1982 \\
\hline Padilla & $15^{\circ} 27^{\prime} \mathrm{S}, 67^{\circ} 06^{\prime} \mathrm{W}$ & - & $1,050 \mathrm{~m}$ & - & $\begin{array}{l}\text { J. Tobias and N. Seddon, } \\
\text { pers. comm. }\end{array}$ \\
\hline Illampu & $15^{\circ} 27^{\prime} \mathrm{S}, 67^{\circ} 09^{\prime} \mathrm{W}$ & $1,350 \mathrm{~m}$ & - & - & $\begin{array}{l}\text { J. Tobias and N. Seddon, } \\
\text { pers. comm. }\end{array}$ \\
\hline $\begin{array}{l}\text { Serranía } \\
\text { Bellavista }\end{array}$ & $15^{\circ} 41^{\prime} \mathrm{S}, 67^{\circ} 30^{\prime} \mathrm{W}$ & - & $1,550 \mathrm{~m}$ & - & Remsen et al. 1982 \\
\hline N Caranavi & c. $15^{\circ} 42^{\prime} \mathrm{S}, 67^{\circ} 30^{\prime} \mathrm{W}(?)$ & - & $1,400 \mathrm{~m}$ & - & Remsen et al. 1982 \\
\hline "Caranavi" & c. $15^{\circ} 45^{\prime} \mathrm{S}, 67^{\circ} 35^{\prime} \mathrm{W}(?)$ & - & $920 \mathrm{~m}$ & - & $\begin{array}{l}\text { Colección Boliviana de } \\
\text { Fauna specimens }\end{array}$ \\
\hline Santa Ana & $15^{\circ} 54^{\prime} \mathrm{S}, 67^{\circ} 34^{\prime} \mathrm{W}$ & $670 \mathrm{~m}$ & $670 \mathrm{~m}$ & - & Carriker 1935 \\
\hline $\begin{array}{l}\text { Mosetén } \\
\quad \text { Communal Lands }\end{array}$ & $16^{\circ} \mathrm{Oo}^{\prime} \mathrm{S}, 66^{\circ} 43^{\prime} \mathrm{W}$ & $720 \mathrm{~m}$ & - & - & This study (SKH) \\
\hline Río Ipiri & $16^{\circ} \mathrm{O} 4^{\prime} \mathrm{S}, 66^{\circ}{ }_{41}^{\prime} \mathrm{W}$ to $16^{\circ} \mathrm{O} 3^{\prime} \mathrm{S}, 66^{\circ} 4 \mathrm{O}^{\prime} \mathrm{W}$ & $640-800 \mathrm{~m}$ & $800 \mathrm{~m}$ & - & This study (SKH) \\
\hline Laguna Carachupa & $16^{\circ} 14^{\prime} \mathrm{S}, 66^{\circ} 25^{\prime} \mathrm{W}$ & $1,200-1,380 \mathrm{~m}$ & $1,250-1,340 \mathrm{~m}$ & Isiboro-Sécure Nacional Park & $\begin{array}{l}\text { This study } \\
\text { (SKH and MK) }\end{array}$ \\
\hline Río Altamachi & $16^{\circ} 24^{\prime} \mathrm{S}, 66^{\circ} 2 \mathrm{o}^{\prime} \mathrm{W}$ & - & $1,250 \mathrm{~m}$ & - & MacLeod et al. 2005 (SKH) \\
\hline El Palmar & $17^{\circ} 05^{\prime} \mathrm{S}, 65^{\circ} 29^{\prime} \mathrm{W}$ to $17^{\circ} 07^{\prime} \mathrm{S}, 65^{\circ} 33^{\prime} \mathrm{W}$ & $700-900 \mathrm{~m}$ & $800 \mathrm{~m}$ & - & $\begin{array}{l}\text { SIST: Bond and Meyer de } \\
\text { Schauensee 1941, this study } \\
\text { (ABH, MK); MYGR: Collar } \\
\text { et al. } 1992\end{array}$ \\
\hline $\begin{array}{l}\text { 40-48 km SW } \\
\text { Villa Tunari }\end{array}$ & $17^{\circ} 06^{\prime} \mathrm{S}, 65^{\circ} 4 \mathrm{o}^{\prime} \mathrm{W}$ & $900-1,090 \mathrm{~m}$ & - & - & $\begin{array}{l}\text { Whitney et al. 1994, S. Kreft, } \\
\text { pers. comm. }\end{array}$ \\
\hline
\end{tabular}


Table 1. Continued.

\begin{tabular}{|c|c|c|c|c|c|}
\hline Locality & Coordinates & SIST & MYGR & $\begin{array}{l}\text { Protected } \\
\text { Area }\end{array}$ & Source \\
\hline Alto Palmar & $17^{\circ} 08^{\prime} \mathrm{S}, 65^{\circ} 35^{\prime} \mathrm{W}$ & $1,100 \mathrm{~m}$ & $1,050-1,250 \mathrm{~m}$ & Carrasco National Park & $\begin{array}{l}\text { SIST: } \\
\text { Louisiana State } \\
\text { University Museum of } \\
\text { Zoology specimen; MYGR: } \\
\text { this study (SKH) }\end{array}$ \\
\hline $\begin{array}{l}\text { Serranía } \\
\text { de Callejas }\end{array}$ & c. $17^{\circ} 09^{\prime} \mathrm{S}, 65^{\circ} 36^{\prime} \mathrm{W}$ & $1,500 \mathrm{~m}$ & - & Carrasco National Park & This study (SKH) \\
\hline Río Saguayo & $17^{\circ} 41^{\prime} \mathrm{S}, 63^{\circ} 44^{\prime} \mathrm{W}^{1}$ & $700-800 \mathrm{~m}$ & $650-1,000 \mathrm{~m}$ & Amboró National Park & $\begin{array}{l}\text { Parker et al. 1992, } \\
\text { N. Renaudin, pers. comm. }\end{array}$ \\
\hline Cerro Hosane & $17^{\circ} 42^{\prime} \mathrm{S}, 64^{\circ} \mathrm{O} 2^{\prime} \mathrm{W}$ & - & $1,200 \mathrm{~m}$ & Amboró National Park & Remsen et al. 1982 \\
\hline Río Macuñucú & $17^{\circ} 44^{\prime} \mathrm{S}, 63^{\circ} 36^{\prime} \mathrm{W}$ & - & $450-500 \mathrm{~m}$ & Amboró National Park & This study (SKH) \\
\hline Serranía La Luna & c. $17^{\circ} 50^{\prime} \mathrm{S}, 64^{\circ} \mathrm{Oo}^{\prime} \mathrm{W}$ & $1,200 \mathrm{~m}$ & - & Amboró National Park & $\begin{array}{l}\text { N. Renaudin and } \\
\text { F. Sagot, pers. comm. }\end{array}$ \\
\hline Santa Rita & $17^{\circ} 56^{\prime} \mathrm{S}, 63^{\circ} 22^{\prime} \mathrm{W}^{2}$ & - & $500 \mathrm{~m}$ & - & Remsen et al. 1982 \\
\hline Río Salado & $18^{\circ} 06^{\prime} \mathrm{S}, 63^{\circ} 33^{\prime} \mathrm{W}$ & $1,400 \mathrm{~m}$ & - & Amboró National Park & Mayer 2000 (F. Sagot recording) \\
\hline Los Volcanes & $18^{\circ} \mathrm{o} 6-07^{\prime} \mathrm{S}, 63^{\circ} 36^{\prime} \mathrm{W}$ & $1,050-1,200 \mathrm{~m}$ & $\begin{array}{l}\text { 1,050 m } \\
\text { (vagrant) }\end{array}$ & $\begin{array}{l}\text { Private Reserve next to } \\
\text { Amboró National Park }\end{array}$ & This study (SKH, MK, VHG) \\
\hline Serranía Raigones & $18^{\circ} 10^{\prime} \mathrm{S}, 63^{\circ} 32^{\prime} \mathrm{W}$ & - & $800 \mathrm{~m}$ & - & Collar et al. 1992 \\
\hline
\end{tabular}

${ }^{1}$ The coordinates for Río Saguayo given by Parker et al. (1992) $\left(17^{\circ} 50^{\prime} \mathrm{S}, 63^{\circ} 39^{\prime} \mathrm{W}\right)$ were an error.

${ }^{2}$ Paynter (1992) stated that his identification of this locality was uncertain and gave coordinates for a site in the lowlands $c$. $15 \mathrm{~km}$ north of Buena Vista, which is at an altitude of $c .300 \mathrm{~m}$ (not $500 \mathrm{~m}$ as given by Remsen et al. 1982) and falls outside the distributional range of Yungas Antwren. The coordinates given here correspond to a semi-deciduous forest site $c .26 \mathrm{~km}$ southwest of Santa Cruz de la Sierra, which matches the altitude given by Remsen $e t$ al. (1982) and is much more likely to be the actual collecting locality. 
and abundant only on scattered, up to $35 \mathrm{~m}$ tall emergent trees (Ficus spp.). (2) Most of the area was covered by regenerating forest of variable age, caused by natural disturbances due to landslides or tree falls. Older regenerating forest differed from mature forest in its lower canopy height (10-20 m), lack of thick-trunked trees, denser understorey, and fewer epiphytes. (3) Less widespread young successional stages were dominated by dense scrub (Panicum sp., Solanum spp., Acalypha spp., Hedyosmum spp.), with emergent trees (Cecropia spp.) to $12 \mathrm{~m}$ tall. (4) Large tracts were formed by up to $15 \mathrm{~m}$ tall Guadua bamboo forest. Within dense bamboo stands very little tree regeneration was observed. (5) Stunted ridge forest occurred at 1,500-1,600 m, with trees 3-12 $\mathrm{m}$ tall (exceptionally to $15 \mathrm{~m}$ ) and thickly covered in liverworts, mosses and vascular epiphytes. Small Chusquea bamboo was frequent, but did not form dense thickets.

Los Volcanes (Table 1 ) is a private 297 ha reserve immediately adjacent to Amboró National Park, depto. Santa Cruz. It is situated on the transition from the tropical humid Yungas to subtropical inter-Andean dry valleys of southern Bolivia and consists of steep sandstone hills intersected by narrow valleys at altitudes of $1,000-1,350 \mathrm{~m}$. Mean annual precipitation is $c$. 1,300 $\mathrm{mm}$ (Herzog and Kessler 2002) and characterized by strong seasonality, with about $80 \%$ of the rainfall occurring from October to April ( $\mathrm{SKH}$, unpubl. data). Topographical factors lead to a marked differentiation of vegetation types, with drought-deciduous (dry) forest on sunny north-facing slopes, semi-deciduous forest on partly shaded slopes and evergreen forest on valley bottoms and adjacent, mostly shaded slopes. Chusquea bamboo was abundant in all forest types with a flowering and fruiting climax in the rainy season (November to March) 2000/2001, followed immediately afterwards by a complete, area-wide bamboo die-off. In 2003 bamboo began to recover slowly, but by late 2005 it was still patchy and not nearly as abundant as during its previous climax.

\section{Methods}

\section{Survey methods}

Rapid assessment surveys were audio-visual and relied heavily on the use of sound recording (Parker 1991) for species documentation and on playback for the identification of unfamiliar bird voices. Field work at most sites aimed at maximizing survey area, covering a new area on most mornings starting with or before the dawn chorus. We kept track of the number of individuals per species observed either consecutively throughout the entire survey (Herzog et al. 2002) or in summary form at the end of each survey day (Hennessey and Gomez 2003). Sound recordings of Bolivian Recurvebill made by $\mathrm{ABH}$ in 1998 were deposited at the Macaulay Library of Natural Sounds (MLNS), Cornell Laboratory of Ornithology, U.S.A., and are included in Mayer (2000). Recordings of Yungas Antwren made by SKH in 1996 are included in Mayer (2000), Schulenberg (2000) and Isler and Whitney (2002).

Additional methods were used at two sites. During a rapid assessment expedition on Cordillera Mosetenes, survey duration and relative abundance of both species allowed for the use of time consuming territory mapping with the help of playback of song sound recordings. SKH also conducted 16-minute point counts during the first three morning hours (beginning at dawn) in an attempt to use distance sampling for population density estimation. However, only eight spatially independent (minimum distance $250 \mathrm{~m}$ ) point count stations could be established along the available survey trails (see below), and a total of 14 counts at those stations resulted in only a single detection each of Bolivian Recurvebill and Yungas Antwren, so point count surveys were not continued. This scarcity of detections probably is at least partly a result of the vocal activity pattern of both species, which vocalize predominantly during the dawn chorus and only very sporadically during the remainder of the morning.

Due to the potential problems of territory mapping with unmarked individuals, the objective was to determine the total number of territories falling into the study area, regardless of whether 
they were completely contained in the area, rather than estimating the absolute size of each territory. An area of about 20 ha at altitudes of 1,200-1,600 m was surveyed intensively along newly cut trails over a 24-day period in August and September 2003. Dense vegetation and steep topography limited field work to the trail system in most of the survey area. A hand-held GPS unit was used to determine the linear horizontal distance between the origin and terminus (or a major shift in direction) of each trail (transect), ignoring minor curves and switchbacks and topographic complexity of the area. Assuming that vocalizations of both species can be detected up to a distance of $50 \mathrm{~m}$ on both sides of a transect (see, e.g., Schieck 1997; the song of Bolivian Recurvebill can certainly be detected at distances $>50 \mathrm{~m}$; authors' pers. obs.), we consider that $100 \mathrm{~m}$ of survey transect covered an effective horizontal survey area of $I$ ha. Thus, total transect length in metres was divided by 100 to obtain the size of the entire survey area in hectares.

All observations of both species on Cordillera Mosetenes were marked on a detailed map drawn with the aid of aerial photographs and a GPS. After two survey weeks, SKH targeted gaps between observation locations of each species with song playback to detect additional territories and/or determine territory limits along the trail system. Special caution was exerted to minimize possible errors in territory limits resulting from the observation of unmarked individuals. Once a pair of either species was located on a given day, SKH walked to the nearest observation point or cluster of points considered to be assignable to a neighbouring territory of that species, followed by the use of song playback broadcast in all directions to elicit a response of the presumed territory holders. If a response to playback came from the direction of the previous encounter the experiment was considered inconclusive. This procedure was repeated daily for most territories during the last 10 days of the survey.

Los Volcanes was initially surveyed by SKH in 1997 as outlined above. From June 2003 to November 2005 birds were monitored monthly by SKH and VHGS using constant effort mist netting, point counts and territory mapping on and in the vicinity of three permanent 1 -ha plots at 1,050-1,200 m. Natural history data from this study on Bolivian Recurvebill are presented in the Supplementary materials.

\section{Range size (extent of occurrence) estimates}

In a recent study determining conservation priorities on the east Andean slope of Peru and northern Bolivia (Young 2007), the extent of occurrence of Bolivian Recurvebill and Yungas Antwren were estimated quantitatively for the first time by GIS-based predictive distribution modelling. Using the inductive model Maxent (Phillips et al. 2006; see also Hernandez et al. 2006) the extent of occurrence of each species was projected based on all known locality records as well as altitude, climate and vegetation data, including current habitat availability derived from Moderate Resolution Imaging Spectroradiometer (MODIS) data (Hernandez 2007). For each species four models varying in the use of the MODIS data were run (no MODIS data, MODIS data unsummarised, summarised by $2 \mathrm{~km}$, summarised by $5 \mathrm{~km}$ ). To evaluate the models, data could not be partitioned into training and evaluation records because of the scarcity and low spatial precision of available locality data. In this situation, review by specialists familiar with the species is often the best method available to determine the modelling procedure that produces the most realistic range prediction (Hernandez et al. 2008). Thus, SKH reviewed the output, determining whether any of the Maxent models produced reasonable results, and if they did, identifying the model and threshold (from the O-I scale Maxent output depicting how well the variables in each pixel match those found where the species has been recorded) that produced the most reasonable map for the species according to our present understanding of its distribution and habitat availability. Predicted areas of distribution where the species is known not to occur were eliminated. The final distribution maps are available at www.natureserve.org/aboutUs/ latinamerica/maps_birds.jsp. 


\section{Results}

Distribution, natural history and vocalizations

Bolivian Recurvebill and Yungas Antwren are now known from a total of 21 and 25 ( 27 when including two vagrant records) localities, respectively, which are fairly evenly distributed along the east Andean slope and extend across a latitudinal range from about $14^{\circ} \mathrm{S}$ to $18^{\circ} \mathrm{S}$ (Table 1 , Figures 1 and 2). Details on records obtained by us and other ornithologists since 1995 are given in the Supplementary materials. Perhaps the most noteworthy of our observations are the first records (sound-recordings) of both species for Peru, obtained by SKH and VHG in 2005 and 2006 at Palmerani-Urubamba (Table $\mathrm{I}$ ) in extreme southeast depto. Puno, less than $3 \mathrm{~km}$ from the

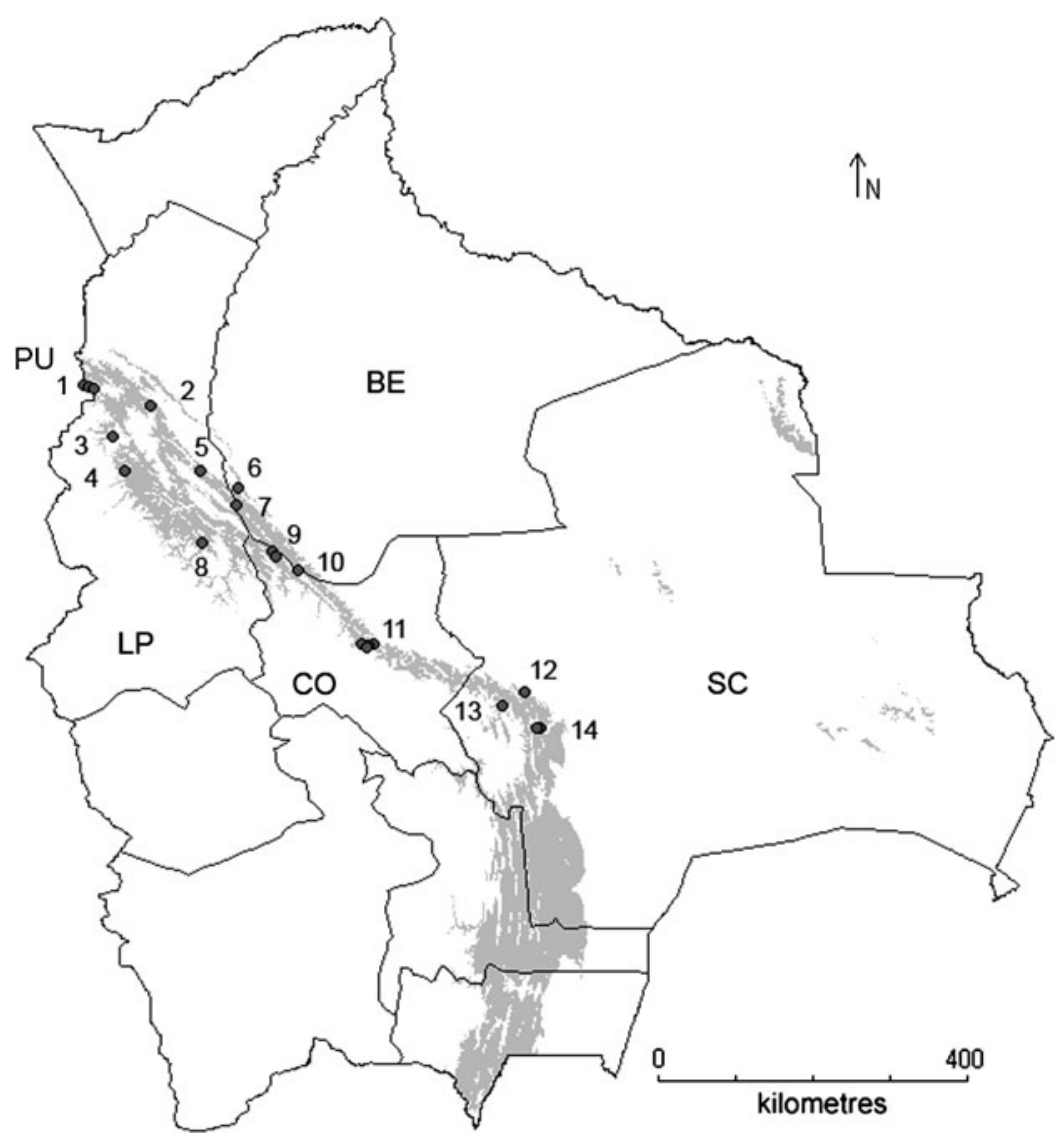

Figure 1. Locality records (dark grey dots) of Bolivian Recurvebill Simoxenops striatus in Bolivia ( $\mathrm{LP}=$ depto. $\mathrm{La} \mathrm{Paz}, \mathrm{BE}=$ depto. Beni, $\mathrm{CO}=$ depto. Cochabamba, $\mathrm{SC}=$ depto. Santa Cruz) and extreme southeast Peru (PU = depto. Puno). Light grey shading denotes areas within the main altitudinal range of the species $(640-1,500 \mathrm{~m})$. Numbers correspond to the following localities or locality clusters: $1=$ Curva Alegre, Palmerani-Urubamba, Río Cocos; $2=$ Serranía Eslabón; 3 = San Miguel Chico; 4 = Cerro Asunta Pata; 5 = Serranía Beu; 6 = Serranía Cuchilla; 7 = Illampu; $8=$ Santa Ana; $9=$ Mosetén Communal Lands, Río Ipiri; 1o = Laguna Carachupa; $11=48 \mathrm{~km}$ by road southwest of Villa Tunari, El Palmar, Alto Palmar, Serranía de Callejas; 12 = Río Saguayo; 13 = Serranía La Luna; 14 = Río Salado, Los Volcanes. 


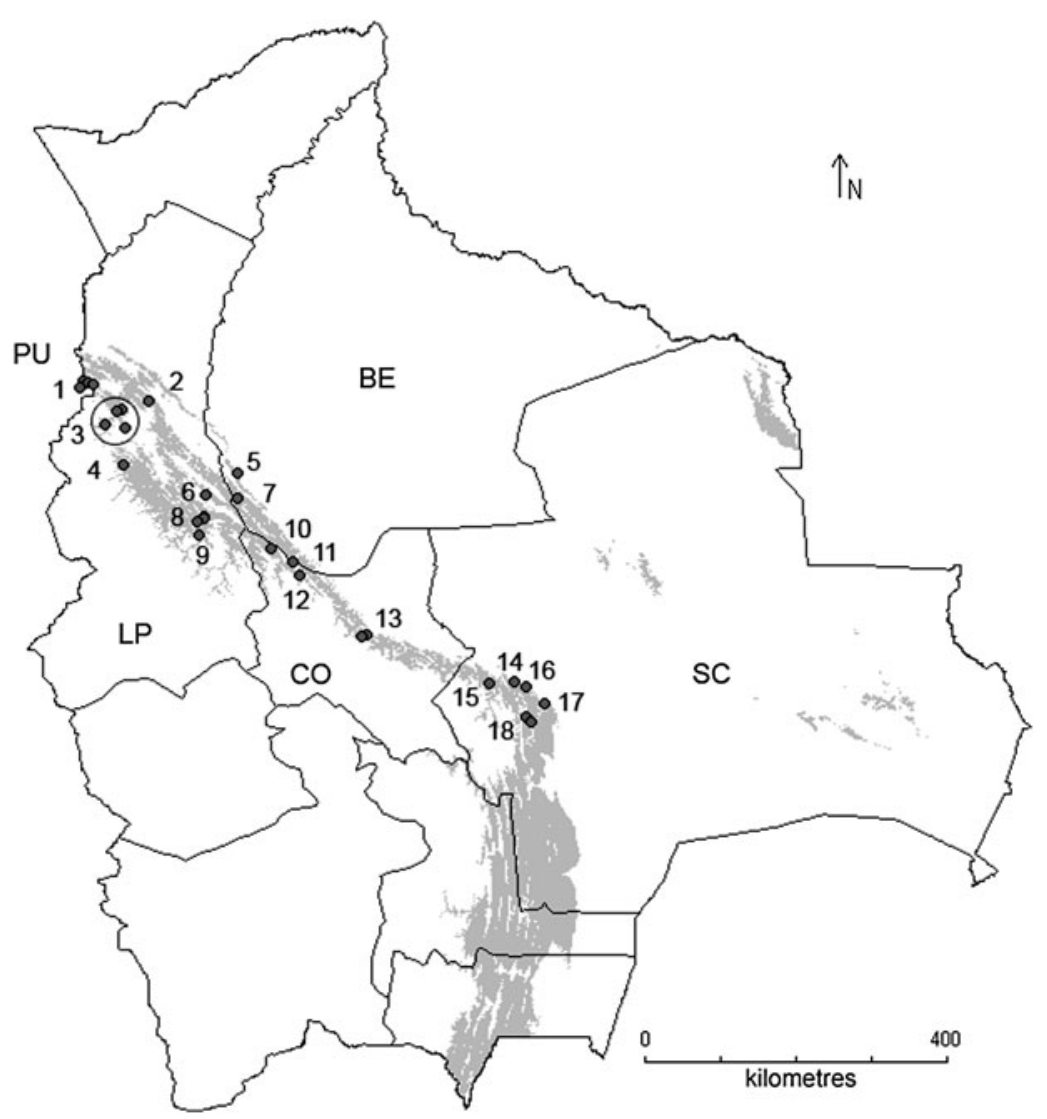

Figure 2. Locality records (dark grey dots) of Yungas Antwren Myrmotherula grisea in Bolivia $(\mathrm{LP}=$ depto. La Paz, BE = depto. Beni, $\mathrm{CO}=$ depto. Cochabamba, $\mathrm{SC}=$ depto. Santa Cruz $)$ and extreme southeast Peru ( $\mathrm{PU}=$ depto. Puno). Light grey shading denotes areas within the main altitudinal range of the species (600-1,400 m). Numbers correspond to the following localities or locality clusters: 1 = Curva Alegre, Palmerani-Urubamba, Río Cocos, Putina Puncu; $2=$ Serranía Eslabón; 3 = Tuichi drainage: Hacienda Ubito, Río Machariapo, Yarimita; 4 = Cerro Asunta Pata; 5 Serranía Pilón; 6 = Río Beni N Puerto Linares; 7 = Padilla; $8=$ Serranía Bellavista, Caranavi; $9=$ Santa Ana; 10 = Río Ipiri; 11 = Laguna Carachupa; 12 = Río Altamachi; 13 = El Palmar, Alto Palmar; $14=$ Río Saguayo; $15=$ Cerro Hosane; $16=$ Río Macuñucú; $17=$ Santa Rita; $18=$ Los Volcanes, Serranía Raigones.

Bolivian border (see Supplementary materials). Prompted by the discovery of Bolivian Recurvebill at this site, a team from the Louisiana State University Museum of Natural Science visited the general area in 2007 and obtained the first Peruvian specimens of both species (D. F. Lane and A. Cuervo, pers. comm.; Table 1 ). Detailed information on the natural history and vocalizations of both species are given in the Supplementary materials.

\section{Range size (extent of occurrence) estimates}

GIS-based predictive distribution modelling produced extent of occurrence estimates of 37,130 $\mathrm{km}^{2}$ for Bolivian Recurvebill and of 29,755 km² for Yungas Antwren (Young 2007). 


\section{Population density and population size estimates}

Along the trail system on Cordillera Mosetenes, covering an effective survey area of 20 ha, SKH determined eight Bolivian Recurvebill and six Yungas Antwren territories using territory mapping and song playback. Under the conservative assumption that only $50 \%$ of the average territory area was contained in the survey area and that a territory is occupied by two adult birds, extrapolated breeding population densities for the Laguna Carachupa area are 20 Bolivian Recurvebill and 15 Yungas Antwren pairs $\mathrm{km}^{-2}$. When further assuming that at least two thirds of the area of Cordillera Mosetenes (c. 2,00o km², see Study area above), excluding areas above the altitudinal range of both species and marginal areas such as the northwestern tip with apparently suboptimal habitat, sustain those population densities, the overall breeding populations on Cordillera Mosetenes consist of about 80,000 Bolivian Recurvebills and 60,000 Yungas Antwrens. Taking into account a conservative error margin of $25 \%$, those values are reduced to a minimum of 60,000 and 45,000 breeding birds, respectively. However, given the potential problems of territory mapping with unmarked individuals (primarily the potential overestimation of the number of territories by the false assignment of the same individual to more than one territory), and the extrapolation from a small study area of $0.2 \mathrm{~km}^{2}$ to an entire mountain range, a cautious interpretation of these values is recommended.

Although we lack similar quantitative data from other areas, it seems safe to conclude that neither species reaches such high densities at most of its other localities. The Río Cocos site (Table I), however, an area with moderately abundant Guadua bamboo, might be an exception for Bolivian Recurvebill. Here, SKH and VHGS evaluated the density of the species somewhat less rigorously. Due to time constraints we made no specific effort to map territories, but we recorded what appeared to be six Bolivian Recurvebill territories in an effective survey area of $c .45$ ha. Although this estimate is not directly comparable to that from Cordillera Mosetenes, given the larger survey area and shorter survey duration at the Río Cocos (see Supplementary materials), similar population densities at both sites seem plausible.

\section{Discussion}

\section{Distribution}

Bolivian Recurvebill and Yungas Antwren are now known from over 20 localities each (Table 1 ), which are distributed much more continuously than previously thought throughout Andean foothills and lower Yungas from depto. Puno in extreme southeast Peru to western depto. Santa Cruz in Bolivia (Figures 1, 2). In addition, the majority of localities of both species are inside or on the border of protected areas (Table 1 ). Their respective altitudinal distributions are also rather similar. That of Bolivian Recurvebill ranges from $640 \mathrm{~m}$ to mostly $1,500 \mathrm{~m}$, locally extending up to $1,700 \mathrm{~m}$ in depto. La Paz (Table 1 ), but perhaps only under special local ecoclimatic conditions in somewhat sheltered valleys that have higher levels of solar insolation than outer Yungas slopes under direct impact from incoming clouds (see Herzog et al. 1999). Yungas Antwren occurs mostly from $600 \mathrm{~m}$ to $1,400 \mathrm{~m}$, but extends locally up to $1,550 \mathrm{~m}$ in depto. La Paz; only at the extreme southern end of its range does it occur at altitudes as low as 450-500 m (Río Macuñucú, Santa Rita; Table 1), presumably due to the absence of lowland congeners from these areas (SKH, pers. obs.). The relative scarcity of records from large parts of depto. Cochabamba (Figures 1, 2) is probably mostly due to the difficult access to appropriate altitudes.

Both species might nonetheless be distributed somewhat patchily in at least parts of their range as some studies in seemingly suitable habitat did not record either species. Such areas include Río Leche (R. MacLeod, in litt.) and Cerro Leñe (SKH, unpubl. data, but see Herzog and Kessler 1998) in eastern depto. Cochabamba, Serranías Sadiri, Tequeje and del Tigre in depto. La Paz (Madidi National Park; Hennessey 2003b) and Serranía Bala in depto. Beni (Hennessey et al. 2003a). 
Serranías Sadiri, Tequeje, del Tigre and Bala are the first foothill ridges in the northern Bolivian Andes that peak at about $900-1,000 \mathrm{~m}$. Although they fall within the altitudinal range of Bolivian Recurvebill and Yungas Antwren, the suitable altitudinal amplitude of only about 300-350 m may be too narrow to sustain viable populations. The notion of a somewhat patchy distribution is further supported by the fact that, although both species inhabit an almost identical geographical range and a very similar altitudinal range, only $12(33 \%)$ of the 36 localities in Table 1 were found to hold both species, which may be related to differences in (micro)habitat use between the two species.

\section{Habitat associations}

Parker et al. (1996) considered Bolivian Recurvebill as having high sensitivity to disturbance. We disagree and suggest classifying the species as having medium sensitivity to disturbance. Although not at high densities, Bolivian Recurvebill has been found in human disturbed habitats at Palmerani, $40 \mathrm{~km}$ southwest of Villa Tunari (S. Kreft, pers. comm.) and at the edge of logging gaps at Río Ipriri (see Supplementary materials). At Laguna Carachupa on Cordillera Mosetenes the dominant vegetation type was regenerating forest of variable age (often with stands of Guadua bamboo) caused by natural disturbances due to landslides or tree falls.

The statement of Ridgely and Tudor (1994) that Bolivian Recurvebill apparently shows no preference for bamboo, which was also implied by Parker et al. 1992 and based on the very limited data available at the time, needs to be revised. The fact that it reaches its highest known population densities in areas where Guadua bamboo is common to abundant (Cordillera Mosetenes, Río Cocos) combined with repeated observations of specialised foraging behaviour on Guadua bamboo (see Supplementary materials) are circumstantial evidence for a strong bamboo preference. However, the species is not an obligate bamboo specialist and persists at often much lower densities in humid and semi-deciduous forest without Guadua bamboo, where it forages in dense understorey or vine tangles, often near tree fall gaps. As observed by SKH at Los Volcanes (see Supplementary materials), it appears to employ similar foraging manoeuvres in these micro-habitats as it does in bamboo stands.

Yungas Antwren was thought to inhabit the mid-storey by Ridgely and Tudor (1994), whereas Zimmer and Isler (2003) considered it a species of mid-storey and subcanopy that descends to the understorey only at forest edge. Data presented here (see Supplementary materials) indicate that Yungas Antwren, like its closest relatives Plain-winged Antwren M. behni, Unicoloured Antwren M. unicolor and Alagoas Antwren M. snowi (the 'plain-winged group'; Whitney 1994, Whitney and Pacheco 1997, Zimmer and Isler 2003), is an understorey species that moves up to mid-level or subcanopy only occasionally while foraging with mixed-species flocks. Its regular occurrence in semi-deciduous forest in depto. La Paz (Perry et al. 1997, this study) also is a rather recent discovery. The presence of typical humid forest species in semi-deciduous and deciduous forest of isolated rain-shadowed valleys embedded in the humid Bolivian Yungas is a general pattern that has only recently been documented to its full extent (Herzog and Kessler 2002, 2006). Nonetheless, the first record of Yungas Antwren from semi-deciduous forest originated from Santa Rita (Remsen et al. 1982; Table 1), depto. Santa Cruz, which went unnoticed due to the erroneous assignment of coordinates to this locality (see footnote 2 in Table 1). T. A. Parker's observation of several individuals on Serranía Raigones, which was mentioned only 'in passing' by Collar et al. (1992), originated from a deciduous forest area where semi-deciduous forest is restricted to narrow gullies (SKH, pers. obs.) at the extreme southern end of the species' range. However, as with nearby Los Volcanes, we consider it unlikely that Serranía Raigones holds a breeding population of Yungas Antwren. Rather, these observations may be related to sourcesink dynamics, where individuals from the core, evergreen areas spill into suboptimal deciduous habitat. 


\section{Range size and population size}

The global extent of occurrence was previously estimated at $19,900 \mathrm{~km}^{2}$ for Bolivian Recurvebill and $32,000 \mathrm{~km}^{2}$ for Yungas Antwren (BirdLife International 2000, 2004, 2007a,b). The most recent estimates obtained by GIS-based predictive distribution modelling (Young 2007) projected a rather similar value of $29,755 \mathrm{~km}^{2}$ for Yungas Antwren, but a notably greater extent of occurrence of $37,130 \mathrm{~km}^{2}$ for Bolivian Recurvebill, which is almost twice as large as that estimated previously. These new estimates thus reconfirm the classification of both species as restricted-range species (see Stattersfield et al. 1998).

The population size of Bolivian Recurvebill and Yungas Antwren was previously thought to be between 2,500 and 10,000 mature individuals (BirdLife International 2004, 2007a,b). Our density estimates from Cordillera Mosetenes indicate that this area alone holds breeding populations of both species of well in excess of 10,000 individuals. Although total population sizes are difficult to estimate due to a lack of quantitative data from other localities, we consider that the global population of both species must number on the order of several tens of thousands of mature individuals. Cordillera Mosetenes seems to be the stronghold for both species, probably due to its high habitat heterogeneity with much natural disturbance and, for Bolivian Recurvebill, the abundance of thick-stemmed Guadua bamboo.

\section{Conservation status}

Bolivian Recurvebill and Yungas Antwren are currently considered 'Vulnerable' (BirdLife International 2007a,b). The latter species is listed based only on IUCN criterion C2a (BirdLife International 2007a), i.e. its population is estimated to number fewer than 10,000 mature individuals and a continuing decline in numbers of mature individuals is observed, projected, or inferred, with no subpopulation estimated to contain more than 1,000 mature individuals. Our density estimates from Cordillera Mosetenes, combined with the new locality records, indicate that the global population size of Yungas Antwren is much greater than 10,000 mature individuals, that the Cordillera Mosetenes subpopulation is much greater than 1,000 mature individuals and that the global population is much less fragmented than previously thought. Criterion $\mathrm{C}_{2}$ a thus does not apply to Yungas Antwren.

Bolivian Recurvebill also is listed under criterion C2a (BirdLife International 2007b), and as with Yungas Antwren, our data strongly suggest that this criterion does not apply to the species. Additional criteria that are thought to apply to Bolivian Recurvebill are B $1 \mathrm{a}+\mathrm{b}$ (BirdLife International $2007 \mathrm{~b}$ ), which estimate the species' extent of occurrence to be less than $20,000 \mathrm{~km}^{2}$, combined with no more than to known localities and a continuing population decline being observed, inferred or projected. The numerous new localities presented above combined with the new extent of occurrence estimate of $37,130 \mathrm{~km}^{2}$ (Young 2007) document that criteria B1a+b also do not apply to Bolivian Recurvebill.

In conclusion, none of the IUCN criteria currently used to assign 'Vulnerable' status to both species (BirdLife International 2007a,b) actually apply, and we recommend that Bolivian Recurvebill and Yungas Antwren be downlisted to 'Near Threatened'. Although no direct evidence for a population decline exists, given their small range it remains a valid threat to both species due to high levels of habitat conversion in the Andean foothills and lower Yungas of Bolivia. Further, even though there remains no doubt that both species have a global population size of well above 10,000 mature individuals, our estimates of $>50,000$ individuals are essentially based on a single locality, and confirmation of our density estimates from additional localities on Cordillera Mosetenes are desirable. Both species have been recorded in several protected areas, but most Bolivian national parks offer little real protection to their threatened species because areas such as Amboró National Park often suffer locally from illegal invasions and forest clearing by subsistence farmers (e.g., Bayá 2006). In addition, under current Bolivian legislation, the exploitation of natural resources has priority over the preservation of protected areas and there remains the risk that these areas could be seriously altered in future extractions of natural resources or road construction projects. 


\section{Other threatened Yungas species}

Six bird species currently considered threatened occur in the humid forests of the Bolivian Yungas (excluding birds of treeline habitats and Polylepis woodlands such as Royal Cinclodes Cinclodes aricomae), and one might wonder if the conservation status of some of them should not also be re-evaluated in light of newly available data. Two are listed as 'Endangered' (Horned Curassow Pauxi unicornis, Yellow-rumped Antwren Terenura sharpei) and four as 'Vulnerable' (Military Macaw Ara militaris, Scimitar-winged Piha Lipaugus uropygialis, Green-capped Tanager Tangara meyerdeschauenseei, Cerulean Warbler Dendroica cerulea) (see www.birdlife.org/datazone/ species/index.html).

The Nearctic-Neotropical migrant Cerulean Warbler reaches the southern terminus of its nonbreeding range in northern Bolivia, where it is known from only a handful of records (see Tobias and Seddon 2007), so virtually nothing can be said about its conservation status based on such data. The situation is similar for Green-capped Tanager, a species formerly considered as endemic to Peru and reported from a single Bolivian locality (Hennessey and Gomez 2003). The status of Scimitar-winged Piha was recently reviewed by Bryce et al. (2005), who recommended continued classification as 'Vulnerable'. The widely distributed Military Macaw, on the other hand, does not appear to be highly threatened in Bolivia, where it is common throughout most of the Yungas of depto. La Paz and northern depto. Santa Cruz (rare to uncommon elsewhere in the Bolivian Andes; authors' unpubl. data), and it is found rather infrequently in the local pet trade (Herrera and Hennessey 2007).

To the contrary, both 'Endangered' species, which are also restricted-range species (Stattersfield et al. 1998), are properly listed as such. Both seem to be naturally rare and are threatened by ongoing, widespread habitat conversion in the foothills and, in the case of Horned Curassow, a high sensitivity to hunting pressure (BirdLife International 2000). Bolivian records of Yellowrumped Antwren are restricted to only three areas in deptos. La Paz and Cochabamba (Cerro Asunta Pata, Louisiana State University Museum of Natural Science specimen; Serranía Bellavista, Remsen et al. 1982, BirdLife International 2000; the Chapare region near San Onofre, Remsen 1982, Brumfield and Maillard 2007), but the species no longer seems to occur on Serranía Bellavista (VHGS, unpubl. data) and has not been found at additional sites despite specific efforts (Hennessey 2004, SKH and VHG, unpubl. data).

\section{Acknowledgements}

Thanks to S.W. Cardiff, A. Cuervo, S. Kreft, D.F. Lane, J.V. Remsen, N. Renaudin, N. Seddon, J.A. Tobias and B.M. Whitney for sharing their unpublished data; to N.H. Rice and K. Zyskowski for information on the whereabouts of Bolivian Recurvebill specimens; to I. Gómez for information on Colección Boliviana de Fauna specimens; and to R. MacLeod, S. Marsden, B.M. Whitney and an anonymous reviewer for comments on an earlier draft of the manuscript. We are grateful to the Bolivian Protected Areas Service (SERNAP) for permission to work in several national parks. M. Fernández, L. Pyritz, R. Soto and D. Soux assisted with mist-netting and ringing in Los Volcanes. SKH's field work was supported by the German Research Council (Deutsche Forschungsgemeinschaft), the German Academic Exchange Service and the Gesellschaft für Tropenornithologie. ABH is grateful for the research opportunities provided by Veterinarians without Borders in Pilón Lajas Biosphere Reserve and by the Living Landscapes Program of the Wildlife Conservation Society (WCS) in Madidi National Park, financed by USAID/Global and WCS International through cooperative agreement LAG-A-oo-99-00047-oo, and additional support from the Gordon and Betty Moore Foundation for the WCS Conserving Landscapes in Amazonia program. The opinions expressed are those of the author and do not necessarily reflect USAID criteria. Field work of MK was supported by the German Research Council. Funds for work at the Altamachi River were obtained by R. MacLeod and A. Maccormick (see MacLeod 
et al. 2005 for a list of funders). The expedition to Laguna Carachupa was made possible by financial support from the Conservation, Research and Exploration Fund of the National Geographic Society, the German Research Council, the Weeden Foundation, BIOPAT and the A.F.W.-Schimper Foundation. The expedition to the confluence of the Santa Elena and Ipiri rivers formed part of the Bolivian Important Biodiversity Areas project of R. MacLeod and A. Maccormick and was supported by the Darwin Initiative Scheme and Conservation International. The expedition to the Río Cocos was funded by the Migratory Bird Program of The Nature Conservancy (D. Mehlman). The support and facilities afforded by Asociación Armonía's Bird Conservation Centre, Bolivian Bird Database and the David Snow Library was invaluable. The Cornell Laboratory of Ornithology's Macaulay Library of Natural Sounds provided equipment loans, tapes and archival assistance to $\mathrm{ABH}$.

\section{References}

Bayá, E. (2006) Boletín electrónico del Área Protegida Amboró. Year 1, $\mathrm{N}^{\circ}$ 4. Available from the first author upon request.

BirdLife International (2000) Threatened birds of the world. Barcelona and Cambridge, UK: Lynx Edicions.

BirdLife International (2004) Threatened birds of the world 2004 (CD-ROM). Cambridge, UK: BirdLife International.

BirdLife International (2007a) Species factsheet: Myrmotherula grisea. Downloaded from http://www.birdlife.org on 6/6/2007.

BirdLife International $(2007 \mathrm{~b})$ Species factsheet: Simoxenops striatus. Downloaded from http://www.birdlife.org on 6/6/2007.

Bond, J. and Meyer de Schauensee, R. (1941) Descriptions of new birds from Bolivia. Part IV. Notula Naturae (Philadelphia), no. 93 .

Brumfield, R. T. and Maillard, O. (2007) Birds of the central Río Paracti valley, a humid montane forest in departamento Cochabamba, Bolivia. Ornitol. Neotrop. 18: 321-337.

Bryce, R., Hennessey, A. B., MacLeod, R., Evans, K., Ewing, S. R., Herzog, S. K., Maccormick, A. and Gomez, M. I. (2005) First sound recordings, new behavioural and distributional records and a review of the status of the globally threatened Scimitarwinged Piha Lipaugus uropygialis. Cotinga 24: 102-106.

Carriker, M. A. Jr. (1935) Descriptions of new birds from Bolivia with notes on little known species. Proc. Acad. Nat. Sci. Philadelphia 87: 313-341.
Collar, N. J., Gonzaga, L. P., Krabbe, N., Madroño Nieto, A., Naranjo, L. G., Parker, III, T. A. and Wege, D. C. (1992) Threatened birds of the Americas. ICBP/IUCN Red Data Book. Cambridge, UK: ICBP.

Hennessey, A. B. (2003a) Catorce nuevos registros altitudinales de aves del bosque húmedo montano, Parque Nacional Madidi, Bolivia. Ecología en Bolivia 38: 121-124.

Hennessey, A. B. (2003b) Base de datos de aves del Parque Nacional Madidi. CDROM. In WCS, CARE, SERNAP, eds. Madidi de Bolivia, mágico, único y nuestro. La Paz, Bolivia: WCS, CARE and SERNAP.

Hennessey, A. B. (2004) A bird survey of Torcillo-Sarayoj, the lower Yungas of Madidi National Park, Bolivia. Cotinga 22: 73-78.

Hennessey, A. B. and Gomez, M. I. (2003) Four bird species new to Bolivia: an ornithological survey of the Yungas site Tokoaque, Madidi National Park. Cotinga 19: 25-33.

Hennessey, A. B., Herzog, S. K., Kessler, M. and Robison, D. (2003a) Avifauna of the Pilón Lajas Biosphere Reserve and communal lands, Bolivia. Bird Conserv. Internatn. 13: 319-349.

Hennessey, A. B., Herzog, S. K. and Sagot, F. (2003b) Lista anotada de las aves de Bolivia. Quinta edición. Santa Cruz de la Sierra, Bolivia: Asociación Armonía/BirdLife International.

Hernandez, P. A. (2007) Métodos para crear los modelos de distribución. Pp. 13-17 in B. E. Young, ed. Distribución de las especies endémicas en la vertiente oriental de los 
Andes en Perú y Bolivia. Arlington, Virginia: NatureServe.

Hernandez, P. A., Franke, I., Herzog, S. K., Pacheco, V., Paniagua, L., Quintana, H. L., Soto, H. A., Swenson, J. J., Tovar, C., Valqui, T. H., Vargas, M. and Young, B. E. (2008) Predicting species distributions in poorly-studied landscapes. Biodivers. Conserv. 17: 1353-1366.

Hernandez, P. A., Graham, C. H., Master, L. L. and Albert, D. L. (2006) The effect of sample size and species characteristics on performance of different species distribution modeling methods. Ecography 29: $773-785$.

Herrera, M. and Hennessey, A. B. (2007) Quantifying the illegal parrot trade in Santa Cruz de la Sierra, Bolivia, with emphasis on threatened species. Bird Conserv. Internatn. 17: 295-300.

Herzog, S. K. and Kessler, M. (1998) In search of the last Horned Curassows Pauxi unicornis in Bolivia. Cotinga 10: 46-48.

Herzog, S. K. and Kessler, M. (2002) Biogeography and composition of dry forest bird communities in Bolivia. J. Ornith. 143: 171-204.

Herzog, S. K. and Kessler, M. (2006) Local versus regional control on species richness: a new approach to test for competitive exclusion at the community level. Global Ecol. Biogeogr. 15: 163-172.

Herzog, S. K., Fjeldså, J., Kessler, M. and Balderrama, J. A. (1999) Ornithological surveys in the Cordillera Cocapata, depto. Cochabamba, Bolivia, a transition zone between humid and dry intermontane Andean habitats. Bull. Brit. Orn. Club 119: 162-177.

Herzog, S. K., Kessler, M. and Bach, K. (2005a) The elevational gradient in Andean bird species richness at the local scale: a foothill peak and a high-elevation plateau. Ecography 28: 209-222.

Herzog, S. K., Kessler, M. and Cahill, T. M. (2002) Estimating species richness of tropical bird communities from rapid assessment data. Auk 119: 749-769.

Herzog, S. K., Soria Auza, R. and Hennessey, A. B. $(2005$ b) Ecoregional patterns of richness, endemism and threat in the Bolivian avifauna: priorities for ecoregional planning. Ecología en Bolivia 40: 27-40.

Isler, P. R. and Whitney, B. M. (2002) Songs of the antbirds: Thamnophilidae, Formicariidae and Conopophagidae (CD). Ithaca, New York: Cornell Laboratory of Ornithology.

Kessler, M. (1999) Plants species richness and endemism during natural landslide succession in a perhumid montane forest in the Bolivian Andes. Ecotropica 5: 123-136.

MacLeod, R., Ewing, S., Herzog, S. K., Bryce, R., Evans, K. L. and Maccormick, A. (2005) First ornithological inventory and conservation assessment for the Yungas forests of the Cordilleras Cocapata and Mosetenes, Cochabamba, Bolivia. Bird Conserv. Internatn. 15: 361-382.

Mayer, S. (2000) Birds of Bolivia 2.0 (CDROM). Westernieland, The Netherlands: Bird Songs International.

Myers, N., Mittermeier, R. A., Mittermeier, C. G., da Fonseca, G. A. B. and Kent, J. (2000) Biodiversity hotspots for conservation priorities. Nature 403: 853-858.

Parker, T. A., III (1991) On the use of tape recorders in avifaunal surveys. Auk 108: 443-444.

Parker, T. A., III and Bailey, B. (eds.) (1991) $A$ biological assessment of the Alto Madidi region and adjacent areas of northwest Bolivia, May 18-June 15, 1990. Conservation International, RAP Working Papers 1.

Parker, T. A., III, Bates, J. M. and Cox, G. (1992) Rediscovery of the Bolivian Recurvebill with notes on other little-known species of the Bolivian Andes. Wilson Bull. 104: $173-178$.

Parker, T. A., III, Stotz, D. F.and Fitzpatrick, J. W. (1996) Ecological and Distributional Databases. Pp. $131-436$ in D. F. Stotz, J. W. Fitzpatrick, T. A. Parker, III and D. K. Moskovits, eds. Neotropical birds: Ecology and conservation. Chicago: University of Chicago Press.

Paynter, R. A. Jr. (1992) Ornithological gazetteer of Bolivia. Cambridge, Massachusetts: Museum of Comparative Zoology.

Perry, A., Kessler, M. and Helme, N. (1997) Birds of the central Río Tuichi valley, with emphasis on dry forest, Parque Nacional Madidi, depto. La Paz, Bolivia. Orn. Monogr. 48: $557-576$. 
Phillips, S. J., Anderson, R. P. and Schapire, R. E. (2006) Maximum entropy modelling of species geographic distributions. Ecol. Modell. 190: 231-259.

Remsen, J. V. Jr. (1984) Natural history notes on some poorly known Bolivian birds, part 2. Gerfaut 74: 163-179.

Remsen, J. V. Jr. and Robinson, S. K. (1990) A classification scheme for foraging behavior of birds in terrestrial habitat. Stud. Avian Biol. 13: 144-160.

Remsen, J. V. Jr. and Traylor, M. A. Jr. (1983) Additions to the avifauna of Bolivia, part 2. Condor 85: 95-98.

Remsen, J. V. Jr., Parker, T. A., III and Ridgely, R. S. (1982) Natural history notes on some poorly known Bolivian birds. Gerfaut 72 : 77-87.

Remsen, J. V. Jr., Schmitt, C. G. and Schmitt, D. C. (1988) Natural history notes on some poorly known Bolivian birds, part 3. Gerfaut 78: 363-381.

Remsen, J. V. Jr., Traylor, M. A. Jr. and Parkes, K. C. (1987) Range extensions for some Bolivian birds, 3 (Tyrannidae to Passeridae). Bull. Brit. Orn. Club 107: 6-16.

Ridgely, R. S. and Tudor, G. (1994) The birds of South America, volume 2. Austin, Texas: University of Texas Press.

Schieck, J. (1997) Biased detection of bird vocalizations affects comparisons of bird abundance among forested habitats. Condor 99: 179-190.

Schulenberg, T. S. (2000) Voices of Andean birds. Volume 1: Birds of the hill forest of southern Peru and Bolivia. Ithaca, New York: Library of Natural Sounds, Cornell Laboratory of Ornithology.
Stattersfield, A. J., Crosby, M. J., Long, A. J. and Wege, D. C. (1998) Endemic bird areas of the world: priorities for bird conservation. Cambridge, UK: BirdLife International.

Tobias, J. A. and Seddon, N. (2007) Nine bird species new to Bolivia and notes on other significant records. Bull. Brit. Orn. Club 127: 49-84.

Vaurie, C. (1980) Taxonomy and geographical distribution of the Furnariidae (Aves, Passeriformes). Bull. Amer. Mus. Nat. Hist. 166: 1-357.

Whitney, B. M. (1994) Behavior, vocalizations, and possible relationships of four Myrmotherula antwrens (Formicariidae) from eastern Ecuador. Auk 111: 469-475.

Whitney, B. M. and Pacheco, J. F. (1997) Behavior, vocalizations, and relationships of some Myrmotherula antwrens (Thamnophilidae) in eastern Brazil, with comments on the "plain-winged" group. Orn. Monogr. 48: 809-819.

Whitney, B. M., Rowlett, J. L. and Rowlett, R. A. (1994) Distributional and other noteworthy records for some Bolivian birds. Bull. Brit. Orn. Club 114: 149-162.

Young, B. E. (ed.) (2007) Distribución de las especies endémicas en la vertiente oriental de los Andes en Perú y Bolivia. Arlington, Virginia: NatureServe.

Zimmer, K. J. and Isler, M. L. (2003) Family Thamnophilidae (Typical Antbirds). Pp. 448-681 in J. del Hoyo, A. Elliott. and D. A. Christie, eds. Handbook of the birds of the world. Vol. 8. Broadbills to Tapaculos. Barcelona: Lynx Edicions.

\section{SEBASTIAN K. HERZOG*}

Asociación Armonía - BirdLife International, Casilla 3566, Santa Cruz de la Sierra, Bolivia. and Institut für Vogelforschung, "Vogelwarte Helgoland", An der Vogelwarte 21, 26386 Wilhelmshaven, Germany.

\section{A. BENNETT HENNESSEY, VÍCTOR H. GARCÍA-SOLÍZ}

Asociación Armonía - BirdLife International, Casilla 3566, Santa Cruz de la Sierra, Bolivia. 


\section{MICHAEL KESSLER}

Albrecht-von-Haller Institut für Pflanzenwissenschaften, Abteilung Systematische Botanik, Untere Karspüle 2, 37073 Göttingen, Germany.

*Author for correspondence; e-mail:skherzog@armonia-bo.org

Received 13 August 2007; revision accepted 7 February 2008 